\title{
2,1,3-Benzothiadiazole Small Donor Molecules: A DFT Study, Synthesis, and Optoelectronic Properties
}

\author{
Dorota Zając $^{1, *}$, Damian Honisz ${ }^{2}$, Mieczysław Łapkowski ${ }^{2,3}$ () and Jadwiga Sołoducho ${ }^{1}$ \\ 1 Faculty of Chemistry, Wrocław University of Science and Technology, Wybrzeże Wyspiańskiego 27, \\ 50-370 Wrocław, Poland; jadwiga.soloducho@pwr.edu.pl \\ 2 Faculty of Chemistry, Silesian University of Technology, Strzody 9, 44-100 Gliwice, Poland; \\ Damian.Honisz@polsl.pl (D.H.); Mieczyslaw.Lapkowski@polsl.pl (M.Ł.) \\ 3 Centre of Polymer and Carbon Materials, Polish Academy of Science, 34 Curie Sklodowska Str., \\ 41-819 Zabrze, Poland \\ * Correspondence: dorota.zajac@pwr.edu.pl; Tel.: +48-7132-023-89
}

check for updates

Citation: Zając, D.; Honisz, D.;

Łapkowski, M.; Sołoducho, J.

2,1,3-Benzothiadiazole Small Donor Molecules: A DFT Study, Synthesis, and Optoelectronic Properties.

Molecules 2021, 26, 1216. https:// doi.org/10.3390/molecules26051216

Academic Editor: Carlos Alemán

Received: 3 January 2021

Accepted: 18 February 2021

Published: 24 February 2021

Publisher's Note: MDPI stays neutral with regard to jurisdictional claims in published maps and institutional affiliations.

Copyright: (c) 2021 by the authors. Licensee MDPI, Basel, Switzerland. This article is an open access article distributed under the terms and conditions of the Creative Commons Attribution (CC BY) license (https:// creativecommons.org/licenses/by/ $4.0 /)$.

\begin{abstract}
We herein report the design and synthesis of small-donor molecules, 2,1,3-benzothiadiazole derivatives ( $2 \mathbf{a}-\mathbf{d})$, by Stille or Suzuki reaction. The synthesized compounds were characterized by spectroscopic and electrochemical methods. The compounds $\mathbf{2 a -} \mathbf{d}$ absorb the light in a wide range (the UV-green/yellow light (2c)) and emit from green to red/near IR light (2c). Furthermore, these compounds show a narrow energy gap (1.75-2.38 eV), and high Ea values increasing for polymers, which prove their electron-donating nature and semiconductor properties. The measurements were enhanced by theoretical modeling.
\end{abstract}

Keywords: benzothiadiazole; small molecules; organic optoelectronic; Stille; Suzuki reaction; conjugated polymers; luminescence materials

\section{Introduction}

Organic semiconductors are currently used in many fields of science, e.g., organic light-emitting diode (OLED), solar cells, transistors, molecular imaging, and sensors [1-7]. Due to their conductive and optical properties, the possibility of easy modification, flexibility, and low production costs, they displace their inorganic counterparts. A recent breakthrough in the performance of organic semiconductor devices has been achieved by developing non-fullerene acceptors (NFAs) that can overcome the drawbacks of fullerenes and have the advantages of high absorption rates, readily tunable optical and electronic properties, and increased solubility [8,9]. Using several variants of the semiconductor structural systems, the properties of the entire system are adjusted, e.g., donor-acceptordonor (D-A-D) molecules $[10,11]$. An example is the use of small molecules, which are currently being intensively studied due to the shortage of n-type conjugated polymer $(n-C P)$ materials as an acceptor in the active layer and a p-type conjugated polymer $(\mathrm{p}-\mathrm{CP})$ as a donor, especially in organic solar cells. Currently, n-CP focuses primarily on perylene diimide, naphthalene diimide, pyridine derivatives, and $\mathrm{p}-\mathrm{CP}$ containing thiophene and dithienosilole [12-17]. However, many of them suffer from some significant weaknesses, such as a poor absorption coefficient and excessively strong crystallinity and stacking, which lead to a limited photocurrent and poor separation in the active layers [18-21]. To overcome the unfavorable properties of some conjugated polymers (CPs), small molecules are being researched, considering their advantages of easy purification, a narrow bandgap, strong absorption, higher electron mobility, well-defined chemical structures, and good photovoltaic performance reproducibility without batch-to-batch variation [22-29].

Herein, to further explore and adjust the properties of novel small molecular donors, 4,7-bis(5-(selenophen-2-yl)thiophen-2-yl)benzothiadiazole (2a) and 4,7-bis(5-(pyridin-2yl)thiophen-2-yl)benzothiadiazole (2b) were designed and synthesized according to our previously reported synthesis of 4,7-bis(5-(3,4-ethylenedioxythiophene)thiophen-2-yl)benzo- 
thiadiazole (2c), as depicted in Scheme 1 [30]. The benzothiadiazole derivatives contained the D-A-D structural motif, based on selenophene, pyridine or 3,4-ethylenedioxythiophene (donor), thiophene (bridge), and benzothiadiazole (BTD, acceptor) from commercially available precursors via only one step. To better understand the dependence of optoelectronic properties on the structure, 4,7-di([2,2'-bithiophen]-5-yl)benzothiadiazole (2d) was also synthesized to compare the effect of thiophene as a substituent in comparison to other groups [31].

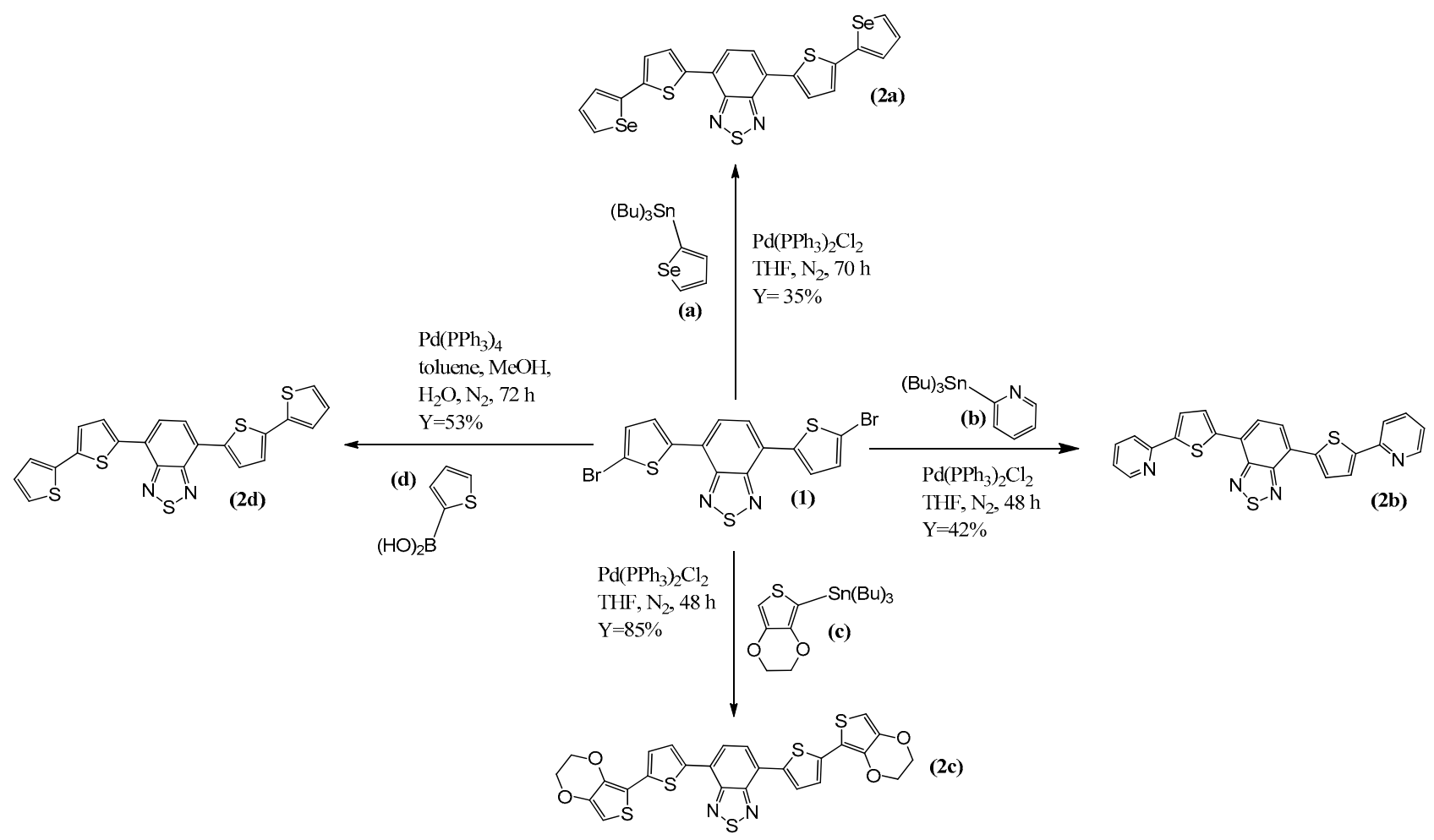

Scheme 1. Synthesis routes of the benzothiadiazole derivatives (2a-d).

\section{Results}

2.1. Synthesis

The synthetic routes and chemical structures of the $\mathbf{2 a}-\mathbf{d}$ molecules are depicted in Scheme 1 . The target small molecules $\mathbf{2 a -} \mathbf{c}$ were obtained through a Stille coupling reaction, and compound $\mathbf{2 d}$ was obtained through a Suzuki coupling reaction. Selenophene and 3,4-ethylenedioxythiophene were monostannylated to 2-(tributylstannyl)selenophene or 2(tributylstannyl)-3,4-ethylenedioxythiophene in $99 \%$ yield with $\mathrm{SnMe} 3 \mathrm{Cl}$ in THF at $-80{ }^{\circ} \mathrm{C}$. All the synthesized compounds were further purified by using a column chromatography technique. The molecular structures of these target compounds and their intermediates were established by using different spectroscopic tools.

\subsection{Theoretical Studies}

Figure 1 shows the optimized structures and frontier molecular orbitals of $\mathbf{2 a - d}$. The HOMO energy level was found to spread throughout the molecules, whereas LUMO was localized on the benzothiadiazole moiety. The HOMO and LUMO energy levels of $\mathbf{2 a}-\mathbf{d}$ are stated in Table 1. The observation, however, should be treated with caution, since the orbital energies are basis set dependent. However, these values are reasonably close to both calculated and experimental ionization energies (Table 1). The efficient small molecule donors should have the HOMO energy levels around $-5.2 \mathrm{eV}$ to ensure acceptable device open circuit voltages [32]. All compounds, except 2c, fulfill this condition. The lowest HOMO orbital has $\mathbf{2 b}(-5.24 \mathrm{eV})$, then $\mathbf{2 d}(-5.12 \mathrm{eV}), \mathbf{2 a}(-5.12 \mathrm{eV})$, and $\mathbf{2} \mathbf{c}$ 
$(-4.78 \mathrm{eV})$. Moreover, the value of the ionization potential suggests the donor properties of the compounds (ionization potential (IP) $<5.7 \mathrm{eV}$ ) (Table 1) [33]. Compound $2 \mathrm{c}$ has the lowest $\mathrm{IP}_{\mathrm{ad}}{ }^{\text {cal }}(5.7 \mathrm{eV})$ compared to compounds $\mathbf{2 a}(6.07 \mathrm{eV}), \mathbf{2 d}(6.08 \mathrm{eV})$, and $\mathbf{2 b}(6.25 \mathrm{eV})$, and therefore has the strongest donor properties. These results differ by approximately $0.5 \mathrm{eV}(2 \mathrm{~d}$ by $0.2 \mathrm{eV})$ from the experimental results, respectively: $5.24 \mathrm{eV}(\mathbf{2 c}), 5.60 \mathrm{eV}$ (2a), $5.86 \mathrm{eV}(\mathbf{2 d})$, and $5.76 \mathrm{eV}(\mathbf{2 b})$. Furthermore, the structure of compounds $\mathbf{2 a}-\mathbf{d}$ is planar, which ensures close intermolecular contacts and high charge carrier mobilities [32]. Figure 2 shows the experimental and calculated UV-vis absorption and photoluminescence spectra of $\mathbf{2 a}-\mathbf{d}$. The corresponding data are summarized in Table 2. It is observed that the $\lambda_{\max }{ }^{\mathrm{cal}}$ of all the structures corresponds to $\mathrm{HOMO} \rightarrow$ LUMO transitions (range in yellow and red light) and to $\mathrm{HOMO} \rightarrow \mathrm{LUMO}+1$ transitions (in the violet range). The calculated $\lambda_{\max }$ value of molecule 2a shows the broadest wavelength with maximum absorption at 413 and $623 \mathrm{~nm}$, which is red-shifted by 58 and $140 \mathrm{~nm}$ when compared with experimental results. The theoretical UV-vis spectra of $\mathbf{2 b}, \mathbf{c}$, and $\mathbf{d}$ are also red-shifted $(110-170 \mathrm{~nm})$ in comparison with experimental results. Moreover, $\mathbf{2 c}$ and $\mathbf{2 d}$ show similar absorption behavior, but $2 \mathrm{c}$ shows broader and red-shifted spectra with the maximum of absorbance at 418 and $652 \mathrm{~nm}$. The compounds $\mathbf{2 a - d}$ have high oscillator strength (f), which corresponds to the appearance of a high experimental absorption coefficient (Table 2).

top view

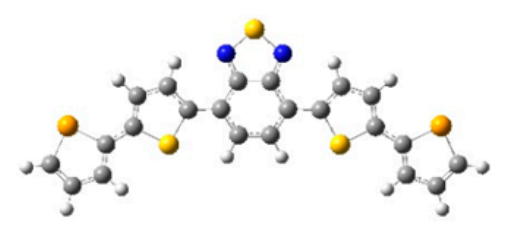

side view

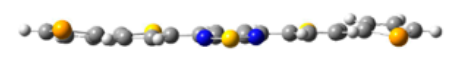

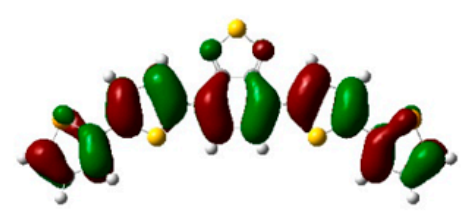

LUMO

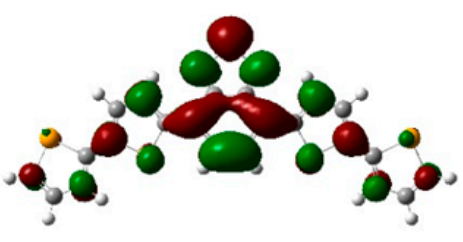

HOMO

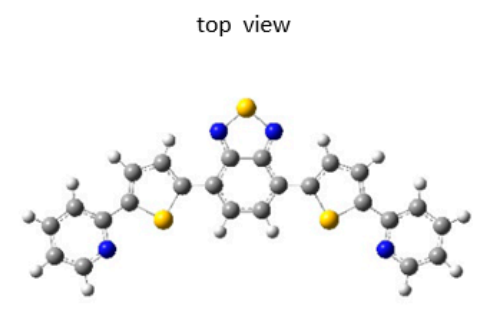

side view

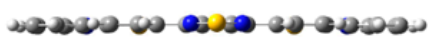

$2 b$

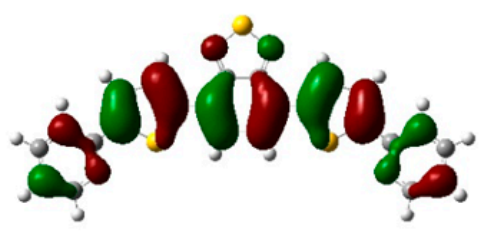

LUMO

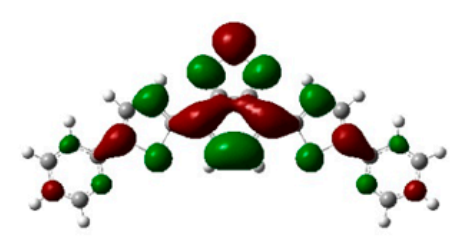

Figure 1. Cont. 


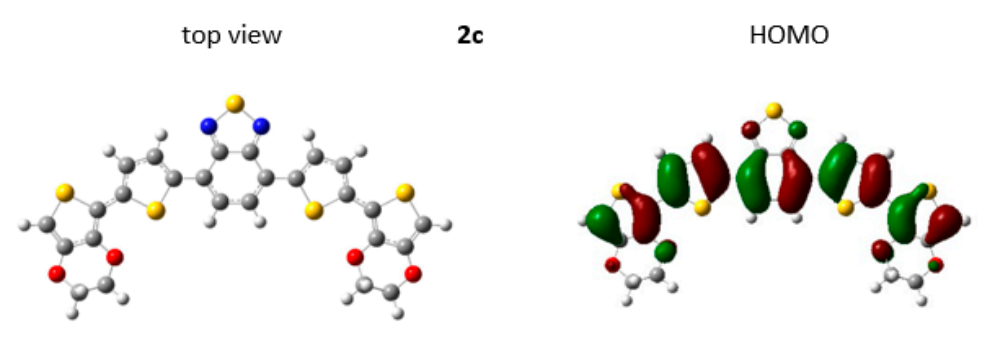

side view

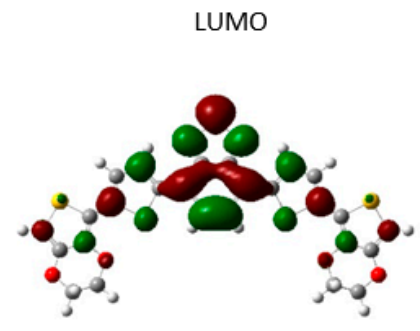

top view

2d

HOMO
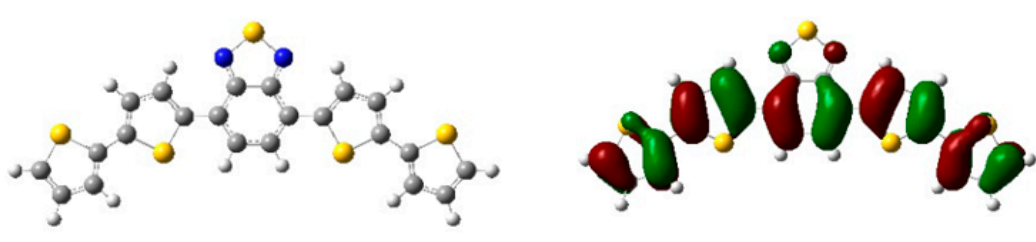

side view

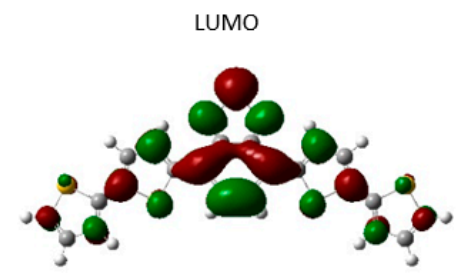

Figure 1. Optimized structures and Frontier molecular orbitals of $\mathbf{2 a - d}$.

Table 1. Redox properties of monomers. $\mathrm{E}^{\mathrm{ox}}{ }_{\text {onset }}$ oxidation peak onset; $\mathrm{E}^{\mathrm{red}}$ onset-reduction peak onset; IP-ionization potential, estimated from the equation $\mathrm{IP}[\mathrm{eV}]=|\mathrm{e}| 5.1+\mathrm{E}^{\mathrm{ox}}{ }_{\text {onset }}[\mathrm{V}]$; EA-electron affinity, estimated from the equation $\mathrm{EA}[\mathrm{eV}]=|\mathrm{e}| 5.1+\mathrm{E}^{\mathrm{red}}{ }_{\text {onset }}[\mathrm{V}] ; \Delta \mathrm{E}_{\mathrm{g}}{ }^{\mathrm{el}}$-electrochemical bandgap from the equation $\Delta \mathrm{E}_{\mathrm{g}}{ }^{\mathrm{el}}=\mathrm{IP}-\mathrm{EA} ; \mathrm{IP}_{\mathrm{ver}}{ }^{\mathrm{cal}}$-calculated

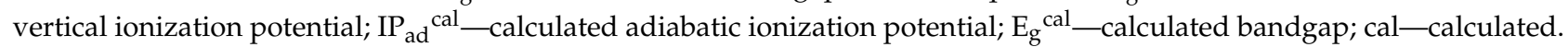

\begin{tabular}{|c|c|c|c|c|c|c|c|c|c|c|}
\hline Compound & $\begin{array}{c}E^{o x} \text { onset } \\
\text { (V) }\end{array}$ & $\begin{array}{c}\text { E }_{\text {red }} \text { onset } \\
\text { (V) }\end{array}$ & $\begin{array}{c}\text { IP } \\
(\mathrm{eV})\end{array}$ & $\begin{array}{c}\text { IP }_{\text {ver }}{ }^{\text {cal }} \\
(\mathrm{eV})\end{array}$ & $\begin{array}{c}\mathrm{IP}_{\mathrm{ad}}^{\mathrm{cal}} \\
(\mathrm{eV})\end{array}$ & $\begin{array}{c}\text { EA } \\
(\mathrm{eV})\end{array}$ & $\begin{array}{c}\text { HOMO }^{\text {cal }} \\
(\mathrm{eV})\end{array}$ & $\begin{array}{c}\text { LUMO }^{\text {cal }} \\
(\mathrm{eV})\end{array}$ & $\begin{array}{l}\mathrm{E}_{\mathrm{g}}^{\mathrm{cal}} \\
(\mathrm{eV})\end{array}$ & $\begin{array}{c}\Delta \mathrm{E}_{\mathrm{g}} \mathrm{el} \\
(\mathrm{eV})\end{array}$ \\
\hline $2 a$ & 0.50 & -1.51 & 5.60 & 6.21 & 6.07 & 3.59 & -5.12 & -2.84 & 2.27 & 2.01 \\
\hline $2 b$ & 0.66 & -1.62 & 5.76 & 6.37 & 6.25 & 3.48 & -5.24 & -2.78 & 2.46 & 2.28 \\
\hline $2 c$ & 0.14 & -1.61 & 5.24 & 5.84 & 5.69 & 3.49 & -4.78 & -2.59 & 2.19 & 1.75 \\
\hline $2 d$ & 0.76 & -1.62 & 5.86 & 6.22 & 6.08 & 3.48 & -5.12 & -2.83 & 2.29 & 2.38 \\
\hline
\end{tabular}



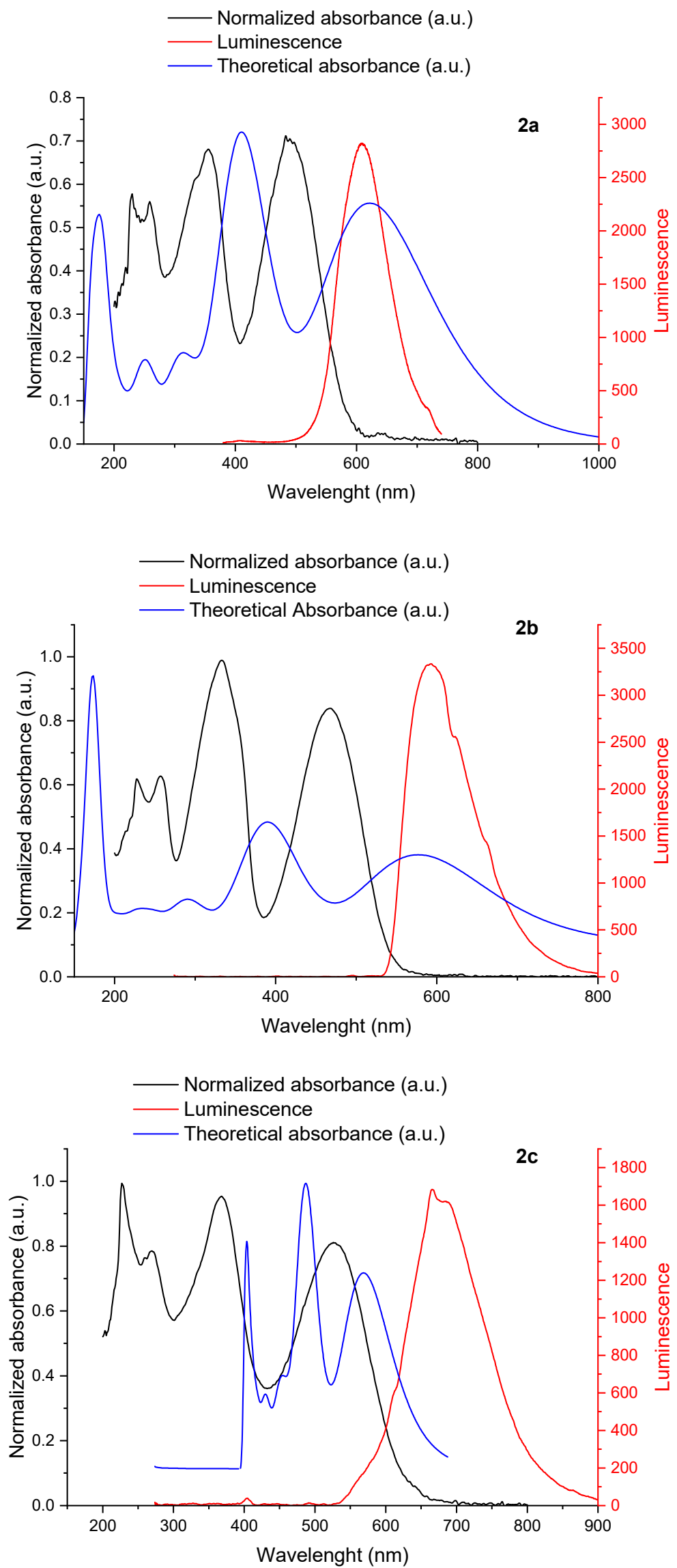

Figure 2. Cont. 


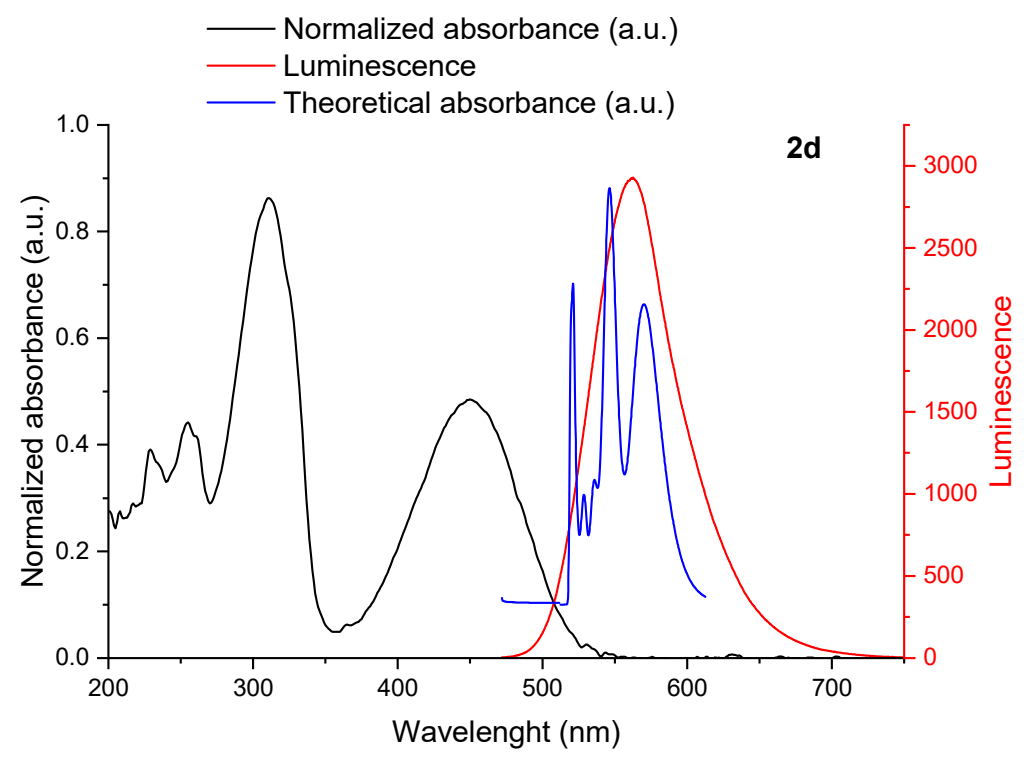

Figure 2. UV-vis experimental absorption (black), theoretical absorption (blue, in vacuum), and emission (red) spectra of compounds $\mathbf{2} \mathbf{a}-\mathbf{d}$ in dichloromethane (DCM).

Table 2. Theoretical properties and maximum of experimental absorption and emission of investigated compounds: $\lambda_{\max }$-maximum wavelength of absorption; $\lambda^{\mathrm{em}}{ }_{\max }$-maximum wavelength of emission; $e x$-experimental; cal—calculated; $f$-oscillator strength.

\begin{tabular}{ccccc}
\hline Compound & $\lambda_{\max }{ }^{\mathbf{e x}}(\mathbf{n m})$ & $\lambda_{\max }{ }^{\text {cal }}(\mathbf{n m})$ & $\lambda^{\text {em }}{ }_{\max }(\mathbf{n m})$ & $f$ \\
\hline \multirow{2}{*}{ 2a } & 355 & $413(\mathrm{H}-\mathrm{L}+1)$ & \multirow{2}{*}{609} & 0.88 \\
& 483 & $623(\mathrm{H}-\mathrm{L})$ & & 0.73 \\
\hline \multirow{2}{*}{$2 \mathbf{b}$} & 332 & $393(\mathrm{H}-\mathrm{L}+1)$ & 592 & 0.86 \\
& 468 & $578(\mathrm{H}-\mathrm{L})$ & \multirow{2}{*}{0.69} \\
\hline \multirow{2}{*}{ 2c } & 370 & $418(\mathrm{H}-\mathrm{L}+1)$ & 667 & 0.91 \\
& 526 & $652(\mathrm{H}-\mathrm{L})$ & & 0.68 \\
\hline \multirow{2}{*}{ 2d } & 311 & $406(\mathrm{H}-\mathrm{L}+1)$ & \multirow{2}{*}{563} & 0.69 \\
\hline
\end{tabular}

\subsection{Photophysical Studies}

The optical properties of synthesized compounds $\mathbf{2 a}-\mathbf{d}$ were studied by UV-vis and fluorescence spectroscopy. The UV-vis absorption and emission spectra of compounds 2a-d in dichloromethane (DCM) are shown in Figure 2, and the corresponding data are summarized in Table 2. Compounds 2a-d show two absorption peaks at 311-370 nm due to the overlap of the $n-\pi^{*}$ and $\pi-\pi^{*}$ transition, whereas absorption maxima at $452-526 \mathrm{~nm}$ are due to a push-pull system, which allows for intramolecular electron density transfer from donor unit to acceptor. Compounds $\mathbf{2} \mathbf{a}, \mathbf{b}$, and $\mathbf{d}$ show luminescence in the range of light from green to red light, with the maximum of emission at 609,592 , and $563 \mathrm{~nm}$, respectively, while compound $2 \mathrm{c}$ is batochromically shifted to near IR, with the maximum of emission at $667 \mathrm{~nm}$. This red shift in the emission spectrum of $\mathbf{2 c}$, as compared to $\mathbf{2 a}, \mathbf{b}$, and $\mathbf{d}$, can be explained in terms of the stronger donor character of ethylenedioxythiophene.

\subsection{Electrochemical Properties}

During the electrochemical oxidation, an irreversible process of polymerization occurs for all monomers. First, Cyclic Voltammetry (CV) scans in the anodic range are presented in Figure $3 b$. The oxidation potential of $\mathbf{2 c}$ was much lower than that of compounds $\mathbf{2 a}$, $\mathbf{2 b}$, and $\mathbf{2 d}$, which subsequently oxidized within a narrow range. This trend for changing substituents is consistent with the literature $[34,35]$ and with calculated values of HOMO. 
During reverse polarization, reduction of oligomers occurs. For $\mathbf{2 d}$, the first oxidation scan's sharp reduction peak suggests dimer formation.
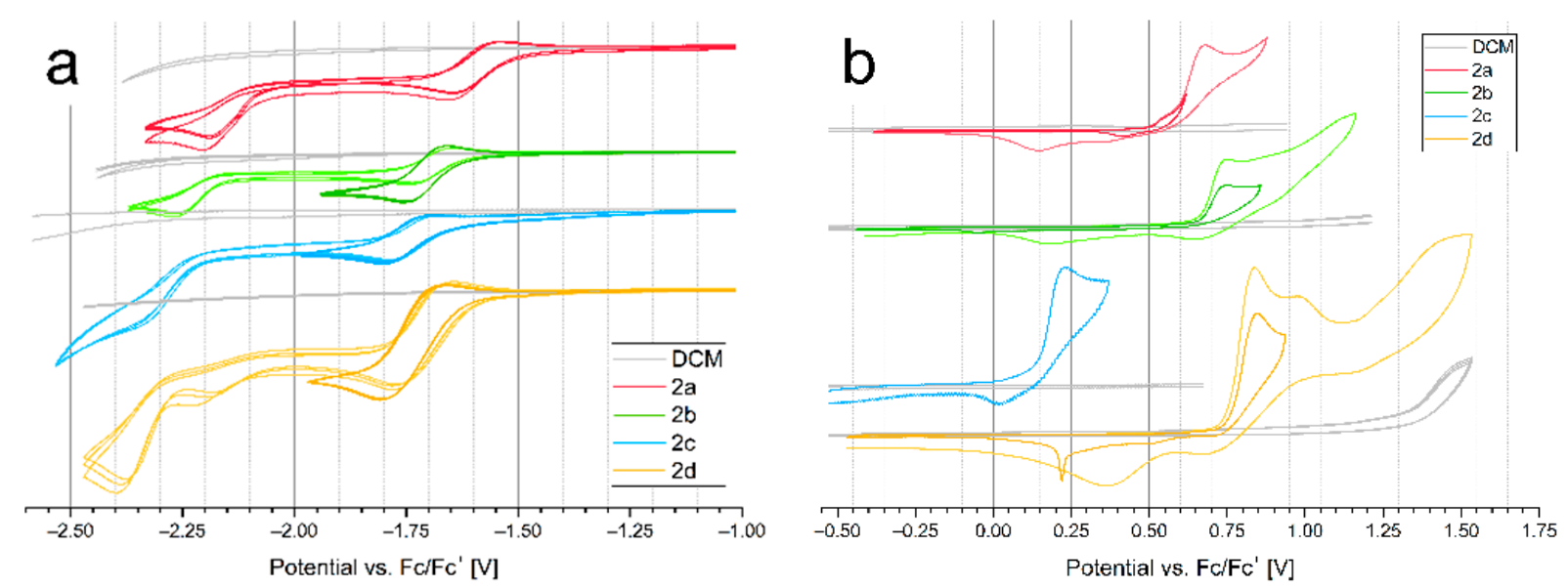

Figure 3. (a) The Cyclic Voltammetry (CV) of reduction of monomers versus ferrocene redox couple, concentration 1 $\mathrm{mmol} / \mathrm{dm}^{3}$ in DCM, $100 \mathrm{mV} / \mathrm{s}$ and background (gray line); (b) the CV of oxidation of monomers versus ferrocene redox couple, concentration $1 \mathrm{mmol} / \mathrm{dm}^{3}$ in $\mathrm{DCM}, 100 \mathrm{mV} / \mathrm{s}$ and background (gray line).

$\mathrm{CV}$ of three reduction scans is presented in Figure 3a. The similar reduction potential of all compounds is caused by the connection of the changing donor unit by the thiophene $\beta$ position and its long distance from the benzothiadiazole unit, where the LUMO is localized. Differently calculated values of LUMO vary between compounds. That indicates that the communication between the D-A parts is slightly overestimated by the density functional theory (DFT), probably by the ideal planarity of the optimized structure. Additionally, the absolute values of LUMO are significantly lower than Electron Affinities, which is usual for the LUMO calculated by the DFT method [36]. Reduction potentials of first quasi-reversible peaks are slightly less electronegative than pure dithienylbenzothiadiazole $(-1.74 \mathrm{~V}$ at onset) [34]. Monomer electrochemical results are summarized in Table 1. All compounds show a narrow band gap $(1.75-2.38 \mathrm{eV})$. The narrowest band gap $\left(\Delta \mathrm{E}_{g}{ }^{\mathrm{el}}\right)$ has $\mathbf{2 c}(-1.75 \mathrm{eV})$, then $\mathbf{2 a}(2.01 \mathrm{eV}), \mathbf{2 b}(2.28 \mathrm{eV})$, and $\mathbf{2 d}(2.38 \mathrm{eV})$. These results correlate well with the theoretical values $\left(\mathrm{E}_{\mathrm{g}} \mathrm{cal}\right)$. The largest difference between the experimental and theoretical results was observed for compound $2 \mathrm{c}(0.44 \mathrm{eV})$, and the smallest for compound 2d $(0.09 \mathrm{eV})$.

Electropolymerization of investigated compounds (Figure 4) forms insoluble films on platinum wire. Polymer CV was conducted under the same conditions as monomers. Three scans of separately registered oxidation and reduction are presented in Figure 5. Polymers $\mathbf{p} 2 \mathbf{b}, \mathbf{p} 2 \mathbf{c}$, and $\mathbf{p 2 d}$ undergo rapid degradation while reducing $\mathbf{2 a}$ also degrades, but slower. During oxidation, $\mathbf{p} \mathbf{2} \mathbf{b}$ and $\mathbf{p} \mathbf{2}$ remain stable, and $\mathbf{p} \mathbf{2 a}$ is stable after the first scan. Only $\mathbf{p} \mathbf{2 d}$ clearly degraded under oxidation. A high drop in p2c oxidation onset in comparison with $2 \mathrm{c}(0.83 \mathrm{~V})$ is characteristic for 3,4-ethylenedioxythiophene (EDOT)-ended monomers and results in a very low bandgap $(0.72 \mathrm{~V})$ [37]. The oxidation potential of polymers $\mathbf{p} 2 \mathbf{d}$ and p2b is similar, but the potential of the latter is lower, like for the corresponding monomers. However, p2a's oxidation potential decreased after polymerization by only approximately $0.33 \mathrm{~V}$. All results for polymers are shown in Table 3. 


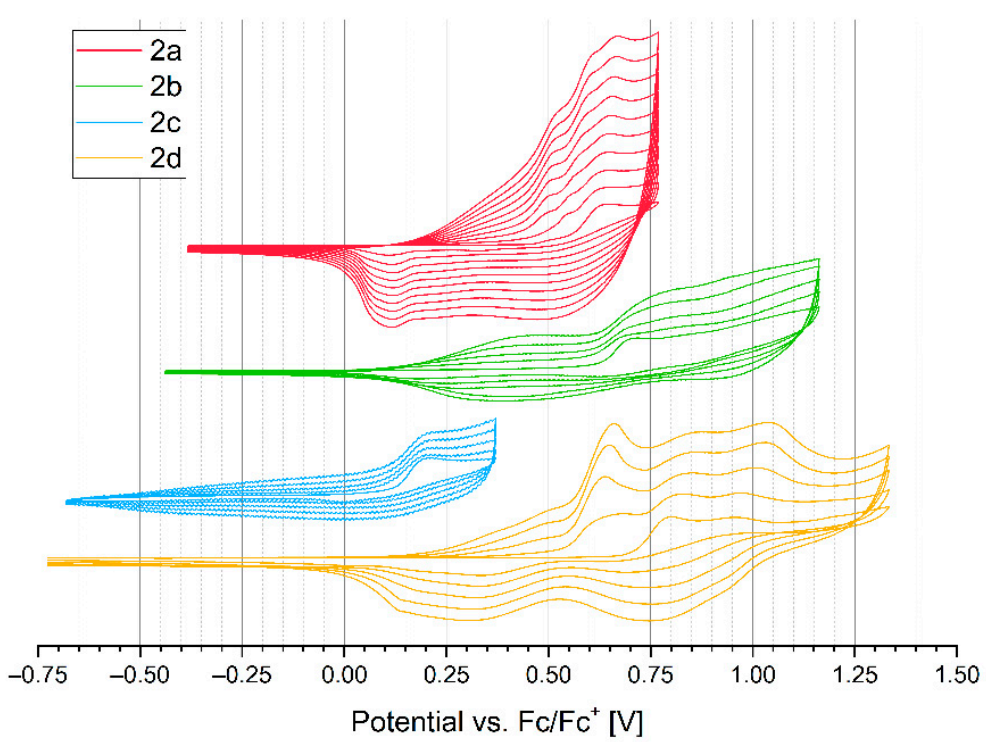

Figure 4. Cyclic polymerization versus ferrocene redox couple, concentration $1 \mathrm{mmol} / \mathrm{dm}^{3}$ in DCM, $100 \mathrm{mV} / \mathrm{s}$.
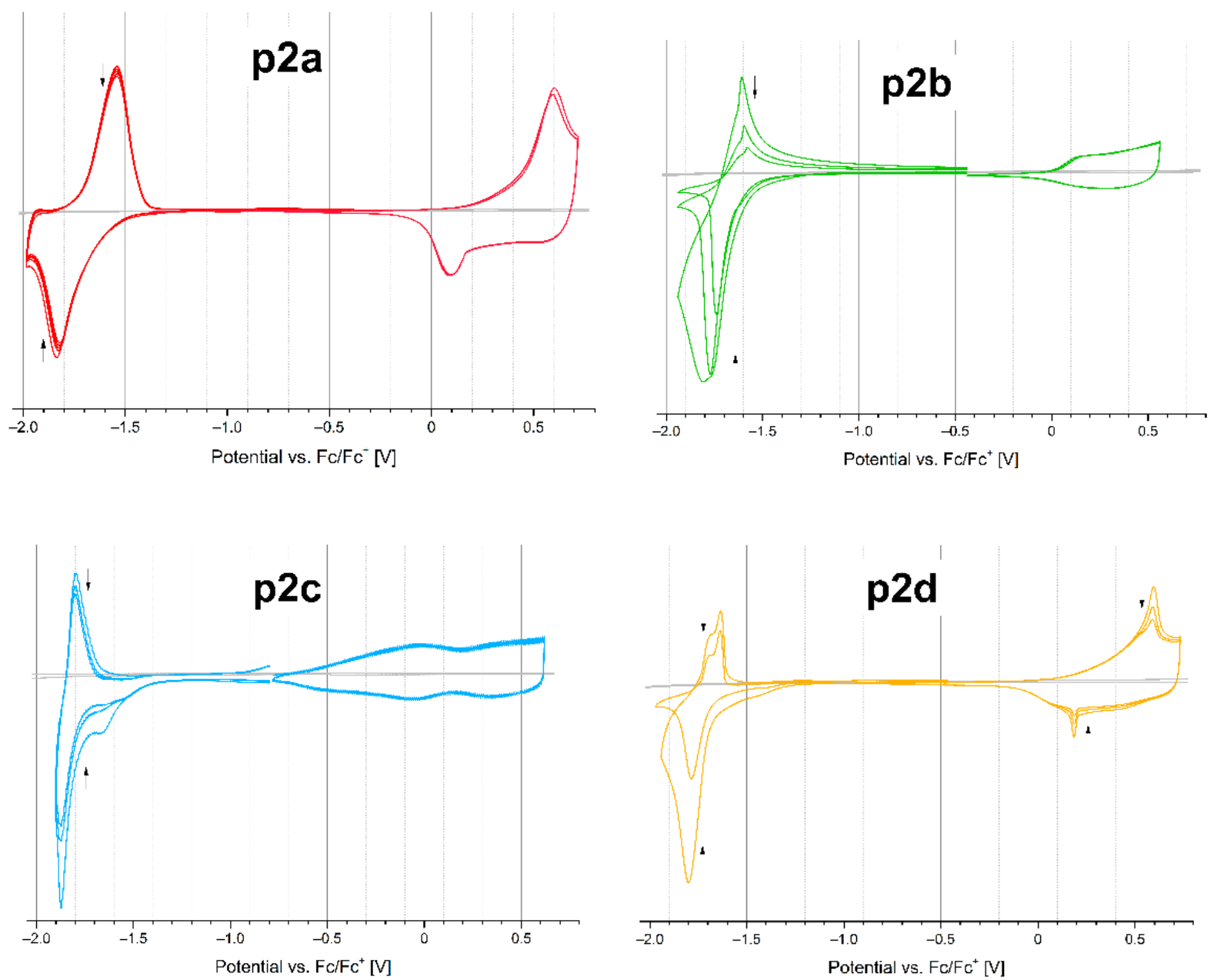

Figure 5. The CV of polymer films p2a-d on Pt wire versus ferrocene redox couple in DCM, $100 \mathrm{mV} / \mathrm{s}$ and background (gray line). 
Table 3. Redox properties of polymers. $\mathrm{E}^{\mathrm{ox}}{ }_{\text {onset }}$-oxidation peak onset; $\mathrm{E}^{\mathrm{red}}{ }_{\text {onset }}$-reduction peak onset; IP-ionization potential, estimated from the equation IP $[\mathrm{eV}]=|\mathrm{e}| 5.1+\mathrm{E}^{\mathrm{ox}}{ }_{\text {onset }}$ [V]; EA-electron affinity, estimated from the equation EA $[\mathrm{eV}]=|\mathrm{e}| 5.1+\mathrm{E}^{\text {red }}{ }_{\text {onset }}[\mathrm{V}]$; $\Delta \mathrm{Eg}_{\mathrm{g}}{ }^{\mathrm{el}}$-electrochemical bandgap, from the equation $\Delta \mathrm{E}_{\mathrm{g}}{ }^{\mathrm{el}}=\mathrm{IP}-\mathrm{EA}$.

\begin{tabular}{cccccc}
\hline Compound & $\mathbf{E}^{\mathbf{o x}}{ }_{\text {onset }}(\mathrm{V})$ & $\mathbf{E}^{\text {red }}{ }_{\text {onset }}(\mathrm{V})$ & IP $(\mathbf{e V})$ & $\mathbf{E A}(\mathbf{e V})$ & $\Delta_{\mathbf{g}}{ }^{\mathbf{e l}}(\mathbf{e V})$ \\
\hline p2a & 0.17 & -1.47 & 5.27 & 3.63 & 1.64 \\
p2b & 0.01 & -1.63 & 5.11 & 3.47 & 1.64 \\
p2c & -0.69 & -1.41 & 4.41 & 3.69 & 0.72 \\
p2d & 0.09 & -1.28 & 5.19 & 3.82 & 1.37 \\
\hline
\end{tabular}

Moreover, compound $2 \mathrm{c}$ was electropolymerized, and the obtained film, poly(4,7bis(5-(3,4-ethylenedioxythiophene)thiophen-2-yl)benzothiadiazole), served as a matrix for an enzyme, horseradish peroxidase (HRP), for $17 \beta$-estradiol detection in an electrochemical biosensor [30]. The detection limit for $17 \beta$-estradiol was set to $105 \mathrm{nM}$, the sensitivity of the proposed biosensor was found to be $1.16 \times 10^{-4} \mathrm{~A} \cdot \mu \mathrm{M}^{-1} \cdot \mathrm{cm}^{-2}$, and the lifetime of the system can be determined for 5 weeks. Compound $\mathbf{2 b}$ also was used in an amperometric, tyrosinase-based biosensor for epinephrine detection [38]. The sensitivity of the proposed biosensor was found to be $3.08 \times 10^{-7} \mathrm{~A} \cdot \mu \mathrm{M}^{-1} \cdot \mathrm{cm}^{-2}$. Poly $(2 \mathrm{c})$ and poly $(2 \mathbf{b})$ serve as electron mediators to improve the flow of electrons between the enzyme's active center and the electrode surface, and they act as a transducer during the transfer of electric charge $[30,38]$. Both of these sensors show a good sensitivity, which confirms the semiconductor nature of the obtained compounds.

\section{Materials and Methods}

\subsection{Computational Details}

The theoretical studies were performed by applying the density functional theory (DFT) method [39]. The calculations were performed utilizing the B3LYP functional [40-42] and the standard cc-pVDZ atomic basis set [43]. The basis set was adopted based on the former experience [44-46]. This basis provides orbital HOMO energies reasonably reproducing directly calculated ionization energies (Table 1). Optical transition of all compounds was studied by conducting Time-dependent density-functional theory (TDDFT) computations [47]. To simulate the UV-vis absorption, spectra and oscillator strength were estimated at their ground-state optimized geometries for a maximum of 200 excited states. All the calculations were carried out using the Gaussian16 suite of codes [48]. The computational resources were provided by the Wroclaw Centre for Networking and Supercomputing (http://wcss.pl). The molecular graphics were produced by applying the GausView program (Gaussian, Inc. Wallingford, Connecticut, USA) [49].

\subsection{Chemistry}

n-Butyllithium (2.5 M in hexane), trimethyltin chloride (1.0 M in THF), 2-(tributylstannyl)pyridine (85\%), 3,4-ethylenedioxytiophene (97\%), selenophene (97\%), 2-thienylboronic acid (95\%), bis(triphenylphosphine)palladium (II) dichloride (98\%), tetrakis(triphenylphosphine)palladium (0) (99\%), and 4,7-bis(5-bromothiophen-2-yl)benzothiadiazole (99\%) were purchased from Sigma Aldrich. Anhydrous potassium carbonate (99\%) was received from Chempur. Anhydrous tetrahydrofuran, toluene, and methanol were purchased from $\mathrm{POCH}$. Tetrahydrofuran was dried over $\mathrm{Na}$ /benzophenone ketal before use. Other commercially available substances and reagents were used without any prior purification. Preparative column chromatography was performed on the glass column with Acros Organics silica gel for chromatography, $0.035-0.075 \mathrm{~mm}, 60 \AA .{ }^{1} \mathrm{H}-\mathrm{NMR}$ and ${ }^{13} \mathrm{C}-\mathrm{NMR}$ spectra were recorded in deuterated chloroform $\left(\mathrm{CDCl}_{3}\right)$ on Brüker Avance III $400 \mathrm{MHz}$ Instruments or on Bruker Avance II 600 Instruments, respectively. Chemical shifts were locked to chloroform $\delta \mathrm{H}$ $7.26(\mathrm{~s})$ and $\delta C 77.16(\mathrm{t})$ signals. The molecular weights of the products were determined using a Brüker micrOTOF-Q spectrometer, FWHM-17500, $20 \mathrm{~Hz}$ (Billerica, MA, USA). The 
percentage composition of the elements was measured on a vario EL cube Analyzer from Elementar Americas (Ronkonkoma, New York, NY, USA).

\subsubsection{Preparation of 4,7-bis(5-(selenophen-2-yl)thiophen-2-yl)benzothiadiazole (2a)}

To a mixture of 4,7-bis(5-bromothiophen-2-yl)benzothiadiazole (1) $(1.00 \mathrm{~g}, 2.18 \mathrm{mmol})$ and 2-(tributylstannyl)selenophene $(2.02 \mathrm{~g}, 4.80 \mathrm{mmol})$ in anhydrous THF $(80 \mathrm{~mL})$, bis(triphenylphosphine)palladium(II) dichloride $\left(\mathrm{Pd}\left(\mathrm{PPh}_{3}\right)_{2} \mathrm{Cl}_{2}\right)(0.31 \mathrm{~g}, 0.436 \mathrm{mmol})$ was added at room temperature under nitrogen atmosphere. The resulting mixture was refluxed with stirring for $70 \mathrm{~h}$. Then, the reaction mixture was concentrated under reduced pressure, diluted with water, and extracted with EtOAc. The extract was washed with brine, dried over $\mathrm{MgSO}_{4}$, and concentrated. The residue was purified by silica gel column chromatography (hexane-EtOAc) to give $\mathbf{2 a}(0.430 \mathrm{~g}, 35 \%)$ as a brown solid.

Mp: $114{ }^{\circ} \mathrm{C}$

${ }^{1} \mathrm{H}-\mathrm{NMR}\left(400 \mathrm{MHz}, \mathrm{CDCl}_{3}\right), \delta(\mathrm{ppm}): \delta 8.11\left(\mathrm{dd}, J_{1}=4.0 \mathrm{~Hz}, J_{2}=5.2 \mathrm{~Hz}, 1 \mathrm{H}\right), 8.02(\mathrm{~d}$, $J=4.0 \mathrm{~Hz}, 1 \mathrm{H}), 7.92\left(\mathrm{dd}, J_{1}=5.2 \mathrm{~Hz}, J_{2}=5.6 \mathrm{~Hz}, 1 \mathrm{H}\right), 7.87-7.83(\mathrm{~m}, 3 \mathrm{H}), 7.46-7.44(\mathrm{~m}, 3 \mathrm{H})$, 7.29-7.27 (m, 1H), 7.21-7.19 (m, 2H).

${ }^{13} \mathrm{C}-\mathrm{NMR}\left(151 \mathrm{MHz}, \mathrm{CDCl}_{3}\right), \delta(\mathrm{ppm}): \delta 152.22,140.54,139.21,138.34,132.37,130.83$, $128.92,128.09,127.72,127.35$.

MS $(m / z):[\mathrm{M}]^{+} 559.1972$

Elemental analysis: calc. (\%) C:47.32; H:2.17; N:5.02; S:17.23; found: C:47.27; H:2.22; N:5.00; S:17.18.

\subsubsection{Preparation of 4,7-bis(5-(pyridin-2-yl)thiophen-2-yl)benzothiadiazole (2b)}

To a mixture of 4,7-bis(5-bromothiophen-2-yl)benzothiadiazole (1) $(1.00 \mathrm{~g}, 2.18 \mathrm{mmol})$ and 2-(tributylstannyl)pyridine (1.77 g, $4.80 \mathrm{mmol})$ in anhydrous THF $(80 \mathrm{~mL})$, bis(triphenylphosphine)palladium(II) dichloride $\left(\mathrm{Pd}\left(\mathrm{PPh}_{3}\right)_{2} \mathrm{Cl}_{2}\right)(0.31 \mathrm{~g}, 0.436 \mathrm{mmol})$ was added at room temperature under nitrogen atmosphere. The resulting mixture was refluxed with stirring for $70 \mathrm{~h}$. Then, the reaction mixture was concentrated under reduced pressure, diluted with water, and extracted with EtOAc. The extract was washed with brine, dried over $\mathrm{MgSO}_{4}$, and concentrated. The residue was purified by silica gel column chromatography (hexane-EtOAc) to give $\mathbf{2 b}(0.417 \mathrm{~g}, 42 \%)$ as a red solid.

Mp: $151-152{ }^{\circ} \mathrm{C}$

${ }^{1} \mathrm{H}-\mathrm{NMR}\left(400 \mathrm{MHz}, \mathrm{CDCl}_{3}\right), \delta(\mathrm{ppm}): \delta 8.64(\mathrm{~d}, J=4.8 \mathrm{~Hz}, 2 \mathrm{H}), 8.18(\mathrm{t}, J=3.4 \mathrm{~Hz}, 2 \mathrm{H})$, $7.95(\mathrm{t}, J=9.4 \mathrm{~Hz}, 2 \mathrm{H}), 7.82-7.78(\mathrm{~m}, 6 \mathrm{H}), 7.15(\mathrm{t}, J=3.4 \mathrm{~Hz}, 2 \mathrm{H})$.

${ }^{13} \mathrm{C}-\mathrm{NMR}\left(151 \mathrm{MHz}, \mathrm{CDCl}_{3}\right), \delta$ (ppm): $\delta 152.57,152.32,152.18,152.04,149.32,141.36$, $140.53,137.05,132.45,130.89,130.72,128.91,128.80,127.33,126.04,125.78,125.68,125.34$, $125.19,125.08$.

MS $(m / z):[\mathrm{M}]^{+} 455.0434$

Elemental analysis: calc. (\%) C:63.41; H:3.10; N:12.32; S:21.16; found: C:63.36; H:3.03; $\mathrm{N}: 12.26 ; \mathrm{S}: 21.11$.

3.2.3. Preparation of 4,7-bis(5-(3,4-ethylenedioxythiophene)thiophen-2-yl)benzothiadiazole (2c)

To a mixture of 4,7-bis(5-bromothiophen-2-yl)benzothiadiazole (1) $(1.00 \mathrm{~g}, 2.18 \mathrm{mmol})$ and 2-(tributylstannyl)-3,4-ethylenedioxythiophene $(2.07 \mathrm{~g}, 4.80 \mathrm{mmol})$ in anhydrous THF (80 mL), bis(triphenylphosphine)palladium(II) dichloride $\left(\mathrm{Pd}\left(\mathrm{PPh}_{3}\right)_{2} \mathrm{Cl}_{2}\right)(0.306 \mathrm{~g}, 0.436$ $\mathrm{mmol}$ ) was added at room temperature under nitrogen atmosphere. The resulting mixture was refluxed with stirring for $48 \mathrm{~h}$. Then, the reaction mixture was concentrated under reduced pressure, diluted with water, and extracted with EtOAc. The extract was washed with brine, dried over $\mathrm{MgSO}_{4}$, and concentrated. The residue was purified by silica gel column chromatography (hexane-EtOAc) to give $2 \mathrm{c}(1.075 \mathrm{~g}, 85 \%)$ as a purple solid.

According to our previous work [30].

Mp: $143-145^{\circ} \mathrm{C}$

${ }^{1} \mathrm{H}-\mathrm{NMR}\left(400 \mathrm{MHz}, \mathrm{CDCl}_{3}\right), \delta(\mathrm{ppm}): \delta 8.07(\mathrm{~d}, J=4.0 \mathrm{~Hz}, 2 \mathrm{H}), 7.83(\mathrm{~s}, 2 \mathrm{H}), 7.30$ $(\mathrm{d}, J=4.0 \mathrm{~Hz}, 2 \mathrm{H}), 6.27(\mathrm{~s}, 2 \mathrm{H}), 4.41-4.39(\mathrm{~m}, 4 \mathrm{H}), 4.28-4.26(\mathrm{~m}, 4 \mathrm{H})$. 
${ }^{13} \mathrm{C}-\mathrm{NMR}\left(151 \mathrm{MHz}, \mathrm{CDCl}_{3}\right), \delta(\mathrm{ppm}): \delta 150.15,146.93,132.46,132.24,130.89,130.52$, $128.80,128.48,123.76,114.70,101.66,90.06,68.72$.

MS $(m / z):[\mathrm{M}]^{+} 580.9799$

Elemental analysis: calc. (\%) C:53.77; H:2.78; N:4.82; S:27.61; found: C:53.75; H:2.75; $\mathrm{N}: 4.79 ; \mathrm{S}: 27.58$.

\subsubsection{Preparation of 4,7-di([2,2'-bithiophen]-5-yl)benzothiadiazole (2d)}

To a mixture of 4,7-bis(5-bromothiophen-2-yl)benzothiadiazole (1) $(1.00 \mathrm{~g}, 2.18 \mathrm{mmol}$ ), 2-thienylboronic acid $(0.64 \mathrm{~g}, 5.02 \mathrm{mmol})$ and potassium carbonate $(0.90 \mathrm{~g}, 6.54 \mathrm{mmol})$ in toluene $(30 \mathrm{~mL}), \mathrm{MeOH}(6 \mathrm{~mL})$, and water $(6 \mathrm{~mL})$, tetrakis(triphenylphosphine)palladium $(0)$ $\left(\mathrm{Pd}\left(\mathrm{PPh}_{3}\right)_{4}\right)(0.126 \mathrm{~g}, 0.109 \mathrm{mmol})$ was added at room temperature under nitrogen atmosphere. The resulting mixture was refluxed with stirring for $72 \mathrm{~h}$. Then, the reaction mixture was concentrated under reduced pressure, diluted with water, and extracted with EtOAc. The extract was washed with brine, dried over $\mathrm{MgSO}_{4}$, and concentrated. The residue was purified by silica gel column chromatography (hexane-EtOAc) to give $2 \mathbf{d}(0.54 \mathrm{~g}, 53 \%)$ as a red solid. According to [31].

Mp: $189-191^{\circ} \mathrm{C}$

${ }^{1} \mathrm{H}-\mathrm{NMR}\left(400 \mathrm{MHz}, \mathrm{CDCl}_{3}\right), \delta(\mathrm{ppm}): \delta 8.12\left(\mathrm{dd}, J_{1}=0.8 \mathrm{~Hz}, J_{2}=3.6 \mathrm{~Hz} 2 \mathrm{H}\right), 7.80$ $(\mathrm{t}, J=4.0 \mathrm{~Hz}, 4 \mathrm{H}), 7.70-7.68(\mathrm{~m}, 2 \mathrm{H}), 7.53-7.51(\mathrm{~m}, 2 \mathrm{H}), 7.15(\mathrm{~d}, J=4.0 \mathrm{~Hz}, 2 \mathrm{H})$.

${ }^{13} \mathrm{C}-\mathrm{NMR}\left(151 \mathrm{MHz}, \mathrm{CDCl}_{3}\right), \delta$ (ppm): $\delta 152.12,140.54,132.46,130.90,130.76,128.85$, $128.14,127.72,127.35,125.69,125.17$.

MS $(\mathrm{m} / \mathrm{z}):[\mathrm{M}]^{+} 463.9600$

Elemental analysis: calc. (\%) C: 56.87; H: 2.60; N: 6.03; S: 34.50; found: C:56.82; H:2.56; $\mathrm{N}: 5.95 ; \mathrm{S}: 34.46$.

\subsection{Optical Measurements}

UV-vis spectra were recorded on the Spectroquant Pharo 300 spectrophotometer (Merck, Darmstadt, Germany). The luminescence spectra were recorded on the Hitachi F2500 fluorescence spectrophotometer (Hitachi High Technologies America, Inc., Pleasanton, CA, USA).

\subsection{Cyclic Voltammetry}

For the cyclic voltammetry (CV) experiments, a three-electrode glass cell was used with a platinum wire as a working electrode, a platinum wire spiral as a counter electrode, and a silver wire reference using $0.1 \mathrm{M} \mathrm{NBu}_{4} \mathrm{PF}_{6}$ (TCI Europe) electrolyte solution in dichloromethane (DCM) (Sigma-Aldrich (Poznan, Poland), Chromasolv, HPLC). The potential sweeps were controlled by a MetrohmAutolab PGSTAT $100 \mathrm{~N}$ potentiostat. The potential of the silver electrode was determined using a ferrocene redox couple $\left(\mathrm{Fc} / \mathrm{Fc}^{+}\right)$for each measurement set, under the same conditions as the measured samples. The solutions were de-aerated with argon before, and argon kept flowing into the cell, above the solution surface, during measurements. A concentration of $1 \mathrm{mmol} / \mathrm{dm}^{3}$ of the monomers was used for both the measurements and polymerization.

\section{Conclusions}

In summary, we have designed and synthesized a series of benzothiadiazole derivatives as donor small molecules with good yield. In the case of the $2 c$ derivative, we obtained up to $85 \%$ yield, which gives an excellent result in the Stille reaction. The $2 \mathbf{a}$ and $\mathbf{2 c}$ compounds absorb the light in the UV-yellow range, and the $\mathbf{2 b}$ and $\mathbf{2} \mathbf{d}$ compounds in the UV-green range. Moreover, these compounds emit in a very wide range $(\mathbf{2} \mathbf{a}, \mathbf{b}$, and $\mathbf{d}$ from green to red and $\mathbf{2 c}$ from green to near IR); therefore, these compounds are very promising optoelectronics materials, e.g., in White OLED (WOLED). In addition, they show a narrow energy gap (1.75-2.38 eV), especially as polymer films $(0.72-1.64 \mathrm{eV})$, and low IP values decreasing for polymers (5.24-5.86 eV for monomers and $4.41-5.27 \mathrm{eV}$ for polymers), 
which proves their electron-donating nature and semiconductor properties. Furthermore, compound $\mathbf{2} \mathbf{c}$ and $\mathbf{2 b}$ served as a conductive matrix for an enzyme in biosensors.

Author Contributions: Conceptualization, D.Z.; Data curation, D.Z. and D.H.; Formal analysis, D.Z. and D.H.; Funding acquisition, D.Z.; Investigation, D.Z. and D.H.; Methodology, D.Z. and D.H.; Project administration, D.Z.; Resources, D.Z.; Software, D.Z.; Supervision, D.Z., M.Ł., and J.S.; Validation, D.Z., M.Ł., and J.S.; Visualization, D.Z. and D.H.; Writing-original draft, D.Z.; Writing-review \& editing, D.Z. and D.H. All authors have read and agreed to the published version of the manuscript.

Funding: This research was funded by National Science Centre, Poland No. 2017/01/X/ST5/00340.

Institutional Review Board Statement: Not applicable.

Informed Consent Statement: Not applicable.

Data Availability Statement: Data can be made available upon written request to the corresponding author and with a proper justification.

Acknowledgments: Calculations have been carried out using resources provided by Wroclaw Centre for Networking and Supercomputing (http:/ / wcss.pl).

Conflicts of Interest: The authors declare no conflict of interest.

Sample Availability: Samples of the compounds $\mathbf{2 a - d}$ are available from the authors.

\section{References}

1. Baldo, M.A.; Thompson, M.E.; Forrest, S.R. High-efficiency fluorescent organic light emitting devices using a phosphorescent sensitizer. Nature 2000, 403, 750-753. [CrossRef]

2. Shu, Y.C.; Gong, Z.H.; Shu, C.F.; Breitung, E.M.; McMahon, R.J.; Lee, G.H.; Jen, A.K.Y. Synthesis and characterization of nonlinear optical chromophores with conformationally locked polyenes possessing enhanced thermal stability. Chem. Mater. 1999, 11, 1628-1632. [CrossRef]

3. van Franeker, J.J.; Bruijnaers, B.J.; Wienk, M.M.; Janssen, R.A.J. Structure-property relationships for bis-diketopyrrolopyrrole molecules in organic photovoltaics. J. Mater. Chem. 2016, 4, 10532-10541. [CrossRef]

4. Mahadik, F.S.S.; Garud, D.R.; Ware, A.P.; Pingale, S.S.; Kamble, R.M. Design, Synthesis and Opto-electrochemical Properties of Novel Donor-Acceptor Based 2,3-di(hetero-2-yl)pyrido [2,3-b]pyrazine amine derivatives as Blue-Orange Fluorescent Materials. Dye. Pigment. 2021, 184, 108742. [CrossRef]

5. Liu, Z.; Hao, F.; Xu, H.; Wang, H.; Wu, J.; Tian, Y. A- $\pi$-D- $\pi-A$ pyridinium salts: Synthesis, crystal structures, two-photon absorption properties and application to biological imaging. CrystEngComm 2015, 17, 5562-5568. [CrossRef]

6. Renkert, S.; Fall, S.; Motamen, S.; Jarrosson, T.; Serein-Spirau, F.; Heiser, T.; Simon, L.; Reiter, G.; Bubendorff, J.L. A new growth process for crystalline ultra-thin layers of conjugated oligomers used in field-effect transistor applications. Appl. Surf. Sci. 2021, 539, 148024. [CrossRef]

7. He, J.; Liang, B.; Yan, X.; Liu, F.; Wang, J.; Yang, Z.; You, R.; Wang, C.; Sun, P.; Yan, X.; et al. A TPA-DCPP organic semiconductor film-based room temperature $\mathrm{NH}_{3}$ sensor for insight into the sensing properties. Sens. Actuators B Chem. 2021, 327, 128940. [CrossRef]

8. Lin, Y.; He, Q.; Zhao, F.; Huo, L.; Mai, J.; Lu, X.; Su, C.-J.; Li, T.; Wang, J.; Zhu, J.; et al. A Facile Planar Fused-Ring Electron Acceptor for As-Cast Polymer Solar Cells with 8.71\% Efficiency. J. Am. Chem. Soc. 2016, 138, 2973-2976. [CrossRef]

9. Chen, F.-X.; Xu, J.-Q.; Liu, Z.-X.; Chen, M.; Xia, R.; Yang, Y.; Lau, T.-K.; Zhang, Y.; Lu, X.; Yip, H.-L.; et al. Near-infrared electron acceptors with fluorinated regioisomeric backbone for highly efficient polymer solar cells. Adv. Mater. 2018, 30, 1803769. [CrossRef]

10. Zhang, H.; Wu, Y.; Zhang, W.; Li, E.; Shen, C.; Jiang, H.; Tian, H.; Zhu, W.H. Low cost and stable quinoxaline-based holetransporting materials with a D-A-D molecular configuration for efficient perovskite solar cells. Chem. Sci. 2018, 9, 5919-5928. [CrossRef]

11. Ding, X.; Chen, C.; Sun, L.; Li, H.; Chen, H.; Su, J.; Li, H.; Li, H.; Xu, L.; Cheng, M. Highly efficient phenothiazine 5,5-dioxidebased hole transport materials for planar perovskite solar cells with a PCE exceeding 20\%. J. Mater. Chem. A 2019, 7, 9510-9516. [CrossRef]

12. Liu, M.; Yang, J.; Yin, Y.; Zhang, Y.; Zhou, E.; Guo, F.; Zhao, L. Novel perylene diimide-based polymers with electron-deficient segments as the comonomer for efficient all-polymer solar cells. J. Mater. Chem. A 2018, 6, 414-422. [CrossRef]

13. Li, Z.; Zhang, W.; Xu, X.; Genene, Z.; Di Carlo Rasi, D.; Mammo, W.; Yartsev, A.; Andersson, M.R.; Janssen, R.A.J.; Wang, E. High-Performance and Stable All-Polymer Solar Cells Using Donor and Acceptor Polymers with Complementary Absorption. Adv. Energy Mater. 2017, 7, 1602722. [CrossRef] 
14. Zhao, R.; Lin, B.; Feng, J.; Dou, C.; Ding, Z.; Ma, W.; Liu, J.; Wang, L. Amorphous Polymer Acceptor Containing B $\leftarrow$ N Units Matches Various Polymer Donors for All-Polymer Solar Cells. Macromolecules 2019, 52, 7081-7088. [CrossRef]

15. Chen, Y.S.; Wan, X.J.; Long, G.K. High Performance Photovoltaic Applications Using Solution-Processed Small Molecules. Acc. Chem. Res. 2013, 46, 2645-2655. [CrossRef]

16. Sun, Y.; Welch, G.C.; Leong, W.L.; Takacs, C.J.; Bazan, G.C.; Heeger, A.J. Solution-Processed Small-Molecule Solar Cells with 6.7\% Efficiency. Nat. Mater. 2012, 11, 44-48. [CrossRef]

17. Zając, D.; Honisz, D.; Łapkowski, M.; Sołoducho, J. Synthesis and Properties of New Dithienosilole Derivatives as Luminescent Materials. Molecules 2019, 24, 2259. [CrossRef]

18. Zhu, L.; Zhong, W.K.; Qiu, C.Q.; Lyu, B.S.; Zhou, Z.C.; Zhang, M.J.; Song, N.; Xu, J.Q.; Wang, J.; Ali, J.; et al. Aggregation-Induced Multilength Scaled Morphology Enabling 11.76\% Efficiency in All-Polymer Solar Cells Using Printing Fabrication. Adv. Mater. 2019, 31, 1902899. [CrossRef]

19. Yan, H.; Chen, Z.; Zheng, Y.; Newman, C.; Quinn, J.R.; Dotz, F.; Kastler, M.; Facchetti, A. A high-mobility electron-transporting polymer for printed transistors. Nature 2009, 457, 679-686. [CrossRef]

20. Kim, T.; Kim, J.H.; Kang, T.E.; Lee, C.; Kang, H.; Shin, M.; Wang, C.; Ma, B.; Jeong, U.; Kim, T.S.; et al. Flexible, highly efficient all-polymer solar cells. Nat. Commun. 2015, 6, 8547. [CrossRef]

21. Benten, H.; Nishida, T.; Mori, D.; Xu, H.; Ohkita, H.; Ito, S. High-performance ternary blend all-polymer solar cells with complementary absorption bands from visible to near-infrared wavelengths. Energy Environ. Sci. 2016, 9, 135. [CrossRef]

22. Walker, B.; Tamayo, A.B.; Dang, X.D.; Zalar, P.; Seo, J.H.; Garcia, A.; Tantiwiwat, M.; Nguyen, T.Q. Nanoscale Phase Separation and High Photovoltaic Efficiency in Solution-Processed, Small-Molecule Bulk Heterojunction Solar Cells. Adv. Funct. Mater. 2009, 19, 3063. [CrossRef]

23. Yuan, J.; Zhang, Y.; Zhou, L.; Zhang, G.; Yip, H.-L.; Lau, T.-K.; Lu, X.; Zhu, C.; Peng, H.; Johnson, P.A.; et al. Single-Junction Organic Solar Cell with over 15\% Efficiency Using Fused-Ring Acceptor with Electron-Deficient Core. Joule 2019, 3, $1140-1151$. [CrossRef]

24. Liu, T.; Luo, Z.; Chen, Y.; Yang, T.; Xiao, Y.; Zhang, G.; Ma, R.; Lu, X.; Zhan, C.; Zhang, M.; et al. A nonfullerene acceptor with a $1000 \mathrm{~nm}$ absorption edge enables ternary organic solar cells with improved optical and morphological properties and efficiencies over 15\%. Energy Environ. Sci. 2019, 12, 2529-2536. [CrossRef]

25. Xu, C.; Wang, J.; An, Q.; Ma, X.; Hu, Z.; Gao, J.; Zhang, J.; Zhang, F. Ternary small molecules organic photovoltaics exhibiting 12.84\% efficiency. Nano Energy 2019, 66, 104119. [CrossRef]

26. Chen, H.; Hu, D.; Yang, Q.; Gao, J.; Fu, J.; Yang, K.; He, H.; Chen, S.; Kan, Z.; Duan, T.; et al. All-Small-Molecule Organic Solar Cells with an Ordered Liquid Crystalline Donor. Joule 2019, 3, 3034-3047. [CrossRef]

27. Yang, L.; Zhang, S.; He, C.; Zhang, J.; Yao, H.; Yang, Y.; Zhang, Y.; Zhao, W.; Hou, J. New wide band gap donor for efficient fullerene-free all-small-molecule organic solar cells. J. Am. Chem. Soc. 2017, 139, 1958-1966. [CrossRef]

28. Deng, D.; Zhang, Y.; Zhang, J.; Wang, Z.; Zhu, L.; Fang, J.; Xia, B.; Wang, Z.; Lu, K.; Ma, W.; et al. Fluorination-enabled Optimal Morphology Leads to over 11\% Efficiency for Inverted Small-molecule Organic Solar Cells. Nat Commun. 2016, 7, 13740. [CrossRef]

29. Gao, K.; Jo, S.B.; Shi, X.; Nian, L.; Zhang, M.; Kan, Y.; Lin, F.; Kan, B.; Xu, B.; Rong, Q.; et al. Over 12\% efficiency nonfullerene all-small-molecule organic solar cells with sequentially evolved multilength scale morphologies. Adv. Mater. 2019, 31, 1807842 [CrossRef]

30. Spychalska, K.; Zajac, D.; Cabaj, J. Electrochemical biosensor for detection of $17 \beta$-estradiol using semi-conducting polymer and horseradish peroxidase. RSC Adv. 2020, 10, 9079-9087. [CrossRef]

31. Jeon, Y.; Kim, T.-M.; Kim, J.-J.; Hong, J.-I. Vacuum-depositable thiophene- and benzothiadiazole-based donor materials for organic solar cells. N.J.Chem. 2015, 39, 9591-9595. [CrossRef]

32. Coughlin, J.E.; Henson, Z.B.; Welch, G.C.; Bazan, G.C. Design and Synthesis of Molecular Donors for Solution-Processed High-Efficiency Organic Solar Cells. Acc. Chem. Res. 2014, 47, 257-270. [CrossRef]

33. Louis, E.; San-Fabián, E.; Díaz-García, M.A.; Chiappe, G.; Vergés, J.A. Are Electron Affinity and Ionization Potential Intrinsic Parameters to Predict the Electron or Hole Acceptor Character of Amorphous Molecular Materials? J. Phys. Chem. Lett. 2017, 8, 2445-2449. [CrossRef]

34. Chen, H.-Y.; Yeh, S.-C.; Chen, C.-T.; Chen, C.-T. Comparison of Thiophene- and Selenophene-Bridged Donor-Acceptor Low Band-Gap Copolymers Used in Bulk-Heterojunction Organic Photovoltaics. J. Mater. Chem. 2012, 22, 21549. [CrossRef]

35. Alghamdi, A.A.B.; Watters, D.C.; Yi, H.; Al-Faifi, S.; Almeataq, M.S.; Coles, D.; Kingsley, J.; Lidzey, D.G.; Iraqi, A. Selenophene vs. Thiophene in Benzothiadiazole-Based Low Energy Gap Donor-Acceptor Polymers for Photovoltaic Applications. J. Mater. Chem. A 2013, 1, 5165. [CrossRef]

36. McCormick, T.M.; Bridges, C.R.; Carrera, E.I.; DiCarmine, P.M.; Gibson, G.L.; Hollinger, J.; Kozycz, L.M.; Seferos, D.S. Conjugated Polymers: Evaluating DFT Methods for More Accurate Orbital Energy Modeling. Macromolecules 2013, 46, 3879-3886. [CrossRef]

37. Ledwon, P.; Thomson, N.; Angioni, E.; Findlay, N.J.; Skabara, P.J.; Domagala, W. The role of structural and electronic factors in shaping the ambipolar properties of donor-acceptor polymers of thiophene and benzothiadiazole. RSC Adv. 2015, 5, 77303-77315. [CrossRef]

38. Meloni, F.; Spychalska, K.; Zajac, D.; Pilo, M.I.; Zucca, A.; Cabaj, J. Application of a Thiadiazole-derivative in a Tyrosinase-based Amperometric Biosensor for Epinephrine Detection. Electroanalysis, under review. 
39. Parr, R.G.; Yang, W. Density Functional Theory of Atoms and Molecules; Oxford University Press: New York, NY, USA, 1994.

40. Becke, A.D. Density functional thermochemistry. III. The role of exact exchange. J. Chem. Phys. 1993, 98, 5648-5652. [CrossRef]

41. Lee, C.; Yang, W.; Parr, R.G. Development of the Colle-Salvetti correlation-energy formula into a functional of the electron density. Phys. Rev. B 1988, 37, 785-789. [CrossRef]

42. Vosko, S.H.; Wilk, L.; Nusair, M. Accurate Spin-Dependent Electron Liquid Correlation Energies for Local Spin Density Calculations: A Critical Analysis. Can. J. Phys. 1980, 58, 1200-1211. [CrossRef]

43. Dunning, T., Jr. H. Gaussian Basis Sets for Use in Correlated Molecular Calculations. I. The Atoms Boron through Neon and Hydrogen. J. Chem. Phys. 1989, 90, 1007-1023. [CrossRef]

44. Zając, D.; Sołoducho, J.; Jarosz, T.; Łapkowski, M.; Roszak, S. Conjugated silane-based arylenes as luminescent materials. Electrochim. Acta 2015, 173, 105-116. [CrossRef]

45. Zając, D.; Sołoducho, J.; Jarosz, T.; Łapkowski, M.; Roszak, S. Efficient Synthesis and Physicochemical Characteristic of Novel Anthracene-based Building Blocks for Optical Materials. Indian J. Appl. Res. 2016, 6, 395-403.

46. Zając, D.; Sołoducho, J.; Jarosz, T.; Łapkowski, M.; Roszak, S. Push-pull structures of symmetric silane derivatives as a novel hosting materials. Indian J. Appl. Res. 2017, 7, 58-66.

47. Runge, E.; Gross, E.K.U. Density-Functional Theory for Time-Dependent Systems. Phys. Rev. Lett. 1984, 52, 997-1000. [CrossRef]

48. Frisch, M.J.; Trucks, G.W.; Schlegel, H.B.; Scuseria, G.E.; Robb, M.A.; Cheeseman, J.R.; Scalmani, G.; Barone, V.; Petersson, G.A.; Nakatsuji, H.; et al. Gaussian 16, Revision C.01; Gaussian, Inc.: Wallingford, CT, USA, 2016.

49. Dennington, R.; Keith, T.A.; Millam, M. GaussView, Version 6.1; Semichem Inc.: Shawnee Mission, KS, USA, 2016. 